\title{
Correction of mineral metabolism in the body of lactating cows during consumption of energy supplements
}

\author{
L.V. Sycheva*, and $O . Y u$. Yunusova \\ FSBEI HE Perm SATU, Department of Animal Husbandry, 23 Petropavlovskaya Str., \\ 614990, Perm, Russia
}

\begin{abstract}
Based on the conducted experiment on the study of energy supplements "Cow Energy" and "Ketostop El" feeding in the diets of lactating cows, their positive effect on the digestibility and accessibility of calcium and phosphorus was noted. Cows of the control group were fed with a multicomponent diet (silage, haylage, grain mix, molasses). The animals of the experimental groups were added energy supplements: I experimental - "Cow Energy" 200 g per head per day, II experimental "Ketostop El" $200 \mathrm{~g}$ per head per day. Cows from the II experimental group were ahead of the control group by $0.40 \%$ and $0.38 \%$ in the use of calcium and phosphorus for milk, and the I experimental group - by $0.04 \%$ and $0.67 \%$. The biochemical analysis of the blood of the experimental cows showed that during the physiological experiment, there were no significant differences in the metabolic processes in the animals. The biochemical parameters of the blood corresponded to the norms of physiological values.
\end{abstract}

\section{Introduction}

Currently, one of the main problems of dairy cattle breeding in Russia is the insufficiently balanced feeding of lactating cows, especially in the first phase of lactation for mineral elements and biologically active substances. This leads to an inefficient use of the animal genetic potential, a decrease in productive longevity, and a violation of reproductive functions $[8,9]$.

With an increase in milk production, metabolic processes associated with an increase in mineral elements in milk are activated in the body of lactating cows. In this regard, industrial technology increases the need for macro- and microelements by $20-25 \%$, depending on the physiological state of cows, age, feeding level, and other factors $[4,5]$.

Mineral substances are of great importance in the process of metabolism, so great attention is given to their presence in the diet. Calcium and phosphorus are the main macronutrients that support metabolism. Thus, calcium helps to reduce the excitability of nervous tissue, excites cardiac activity, participates in the process of blood clotting,

\footnotetext{
* Corresponding author: lvsycheva@mail.ru
} 
activates a number of enzymes, and phosphorus participates in the processes of glycolysis and glycogenolysis, the oxidation of higher fatty acids, the breakdown of proteins, etc. Both of these elements are included in large quantities in the composition of bone tissue. To ensure the process of metabolism in the body, a certain ratio of calcium and phosphorus is necessary. Lack of calcium after calving negatively affects the health of lactating cows. Thus, calcium performs the contractile function of smooth muscles, participates in the mechanism of the immune response to various antigens [6,7].

Practical experience shows that the realization of anumal genetic potential and preservation of productive longevity fully depends on the provision of biologically complete feeding, which can be achieved with the use of various feed additives, the use of which activates the metabolism.

The purpose of this research was to study the effect of energy supplements use in the diet of lactating cows in the first phase of lactation on the exchange of calcium and phosphorus.

Research tasks:

1. to determine the effect of energy supplements on the balance of calcium and phosphorus in the body of cows during the milking period;

2. to analyze blood biochemical parameters that characterize the exchange of calcium and phosphorus;

3. to study the indicators of milk productivity.

\section{Material and research methods}

Studies on the effect of feeding energy supplements on mineral metabolism were conducted in the conditions of a milk production farm. For the economic experiment, cows were selected at the age of the second or third lactation, the weight of the animals was 550-580 $\mathrm{kg}$. To participate in the experiment, 30 clinically healthy cows were selected, they were divided into three groups: two experimental and one control group. The animals were selected according to the method of similar groups, taking into account the productivity for the previous lactation, weight, genotype, and physiological state. The cows were kept in a typical cowshed on a leash, the temperature, humidity, and air movement were the same for the experimental animals. Diets for cows were compiled based on detailed feeding standards for lactating cows [3]. They consisted of feed produced on the farm: bulky feed $20 \mathrm{~kg}$ of mixed-grass silage, $12 \mathrm{~kg}$ - alfalfa haylage; concentrated feed $-10.4 \mathrm{~kg}$ of grain mixture of barley, oats and wheat, $2 \mathrm{~kg}$ - beet molasses. To normalize the diets for minerals and vitamins, table salt, precipitate and premix were included. Cows of the control group were fed with a multicomponent diet (silage, haylage, grain mix, molasses). The animals of the experimental groups were added energy supplements: I experimental - "Cow Energy" $200 \mathrm{~g}$ per head per day, II experimental - "Ketostop El" $200 \mathrm{~g}$ per head per day. The supplements were fed in a mixture with concentrates twice a day before milking in the morning and in the evening. Feed supplements "Cow Energy" and "Ketostop El" are produced in the Russian Federation. According to the manufacturers' recommendations, feed additives were fed 14 days before calving and 28 days after calving.

For the physiological experiment, three cows from each group were selected, the purpose of which was to determine the balance of calcium and phosphorus in the body of dairy cows in the first phase of lactation when consuming energy supplements [1]. During the balance experiment, the conditions for feeding and keeping of experimental animals were observed in a way similar to the scientific and economic experience. The balance experience includes the following periods: preliminary and accounting. During the accounting period, a daily record was kept for each animal for the specified feed, the amount of uneaten residues, the milk produced, and the amount of excreted feces and urine. 
At the end of the accounting period, blood was collected from the jugular vein in the morning before feeding to assess the biochemical status.

The analysis of the chemical composition of biological objects was carried out according to generally accepted methods in the laboratory for the development of agroanimal technologies of the FSBEI HE Perm SATU.

The digital material obtained in the study was processed by the method of variation statistics using the Student confidence criterion at $\mathrm{P} \leq 0.05$ in relation to the control group [2].

\section{Results and discussion}

During the accounting period of the physiological experiment, in fact, the cows of the control group ate bulky feed in the amount of $89.7 \%$ of the daily feed, concentrated $100 \%$, the I experimental group - bulky $-90.9 \%$, concentrated $-100 \%$, and the animals of the II experimental group - bulky $-95.9 \%$, concentrated - $100 \%$ of the daily feed (Table 1 ).

Table 1. Cow feeding diets during the period of physiological experiment (taking into account the actual edibility).

\begin{tabular}{|c|c|c|c|}
\hline \multirow{2}{*}{ Indicator } & \multicolumn{3}{|c|}{ Group } \\
\cline { 2 - 4 } & control & $\begin{array}{c}\text { I } \\
\text { experimental }\end{array}$ & $\begin{array}{c}\text { II } \\
\text { experimental }\end{array}$ \\
\hline \multicolumn{3}{|c|}{ Daily freed } \\
\hline Mixed-grass silage, kg & 18.2 & 18.9 & 19.4 \\
\hline Alfalfa haylage, kg & 10.5 & 10.2 & 11.3 \\
\hline Barley grain, groats, kg & 3.6 & 3.6 & 3.6 \\
\hline Wheat grain, groats, kg & 3.6 & 3.6 & 3.6 \\
\hline Oat grain, groats, kg & 3.2 & 3.2 & 3.2 \\
\hline Beet molasses, kg & 2.0 & 2.0 & 2.0 \\
\hline Table salt, g & 136.0 & 136.0 & 136.0 \\
\hline Precipitate, g & 100.0 & 100.0 & 100.0 \\
\hline Premix P 60-1, g & 120.0 & 120.0 & 120.0 \\
\hline Cow Energy, g & - & 200.0 & - \\
\hline Ketostop EL, g & - & - & 200.0 \\
\hline
\end{tabular}

Due to the introduction of energy supplements "Cow Energy" and "Ketostop El", experimental cows with a diet consumed more energy by $7 \mathrm{MJ}$ and $12 \mathrm{MJ}$ than control animals. For one centner of live weight, the cows of the control group ate $3.75 \mathrm{~kg}$ of dry matter, the I experimental group $-3.76 \mathrm{~kg}$, the animals of the II experimental group -3.78 $\mathrm{kg}$ (Table 2).

The ME content in DM in the control group is 9.3 MJ, in the I experimental group - 9.6 and in the II experimental group - 9.8 MJ. One energy feed unit contained $103.2 \mathrm{~g}$ of digestible protein in the control group, $101.7 \mathrm{~g}$ in the I experimental group, and $103.4 \mathrm{~g}$ in the II experimental group.

The ratio of sugar amount to digested protein amount is $0.95-0.96$, the ratio of calcium to phosphorus is $1.4: 1$, the amount of raw fiber in dry matter is $18.2-18.7 \%$. 
Table 2. Total nutritional value of experimental cows' diets during physiological experiment period (taking into account the actual edibility).

\begin{tabular}{|c|c|c|c|}
\hline \multirow{2}{*}{ Indicator } & \multicolumn{3}{|c|}{ Group } \\
\cline { 2 - 4 } & control & I experimental & II experimental \\
\hline EFU & 19.1 & 19.8 & 20.3 \\
\hline Metabolic energy, MJ & 191 & 198 & 203 \\
\hline Dry matter, g & 20620 & 20702 & 20814 \\
\hline Crude protein, g & 3017 & 3042 & 3093 \\
\hline Digestible protein, g & 1972 & 2014 & 2097 \\
\hline Crude fiber, g & 3746 & 3804 & 3900 \\
\hline Sugar, g & 1882 & 1911 & 2003 \\
\hline Calcium, g & 137.1 & 139.5 & 142.4 \\
\hline Phosphorus, g & 96.7 & 98.2 & 100.3 \\
\hline Table salt, g & 136 & 136 & 136 \\
\hline Carotene, mg & 861 & 874 & 888 \\
\hline ME content in DM, MJ & 9.3 & 9.6 & 9.8 \\
\hline $\begin{array}{c}\text { Content of digestible } \\
\text { protein in EFU, g }\end{array}$ & 103.2 & 101.7 & 103.4 \\
\hline Sugar-protein ratio & 0.95 & 0.95 & 0.96 \\
\hline Ca: P ratio & $1.4: 1$ & $1.4: 1$ & $1.4: 1$ \\
\hline $\begin{array}{c}\text { Crude fiber content in dry } \\
\text { matter, \% }\end{array}$ & 18.2 & 18.4 & 18.7 \\
\hline
\end{tabular}

In general, the main ratios of nutrients in the diets of experimental cows corresponded to the detailed feeding standards of All-Russian Institute of Animal Breeding (2003).

During the period of intensive milk production, the need for mineral substances, in particular calcium and phosphorus, which are part of the biological fluid, increases. Therefore, it is necessary to control the intake of calcium and phosphorus from feed and their release from the body of lactating animals. With the feed, the cows of the control group consumed $137.1 \mathrm{~g}$ of calcium, the animals of the I experimental group $-139.5 \mathrm{~g}$ and of the II experimental group - $142.4 \mathrm{~g}$ (Table 3).

Table 3. Calcium balance and use, $g / d a y, ~(n=3)$.

\begin{tabular}{|c|c|c|c|}
\hline \multirow{2}{*}{ Indicator } & \multicolumn{3}{|c|}{ Group } \\
\cline { 2 - 4 } & control & I experimental & II experimental \\
\hline Taken with feed & 137.1 & 139.5 & 142.4 \\
\hline Excreted in feces & $67.82 \pm 2.04$ & $68.93 \pm 1.08$ & $70.27 \pm 1.32$ \\
\hline Excreted in urine & $14.61 \pm 0.28$ & $14.19 \pm 0.39$ & $14.16 \pm 0.41$ \\
\hline Excreted in milk & $38.24 \pm 0.48$ & $39.41 \pm 0.97$ & $40.28 \pm 0.54^{*}$ \\
\hline Held in body & $16.43 \pm 0.36$ & $16.97 \pm 0.42$ & $17.69 \pm 0.28^{*}$ \\
\hline Total use from intake, \% & $39.87 \pm 0.47$ & $40.41 \pm 0.51$ & $40.71 \pm 0.77$ \\
\hline incl. for milk, \% & $27.89 \pm 0.33$ & $28.25 \pm 0.28$ & $28.29 \pm 0.36$ \\
\hline
\end{tabular}

Note: * Hereafter, the difference is significant with respect to the control group at $\mathrm{P} \leq 0.05$

Animals of the II experimental group, who consumed the energy supplement "Ketostop El" as part of the diet, excreted $70.27 \mathrm{~g}$ of calcium with feces, which is $3.61 \%$ and $1.94 \%$ more than in the control and I experimental groups, respectively. In the control group, calcium excretions were $67.82 \mathrm{~g}$ with feces, which is $1.61 \%$ and $3.49 \%$ less, and $14.61 \mathrm{~g}$ with urine, which is $2.96 \%$ and $3.18 \%$ more than in the experimental groups. The animals 
of the control group isolated $38.24 \mathrm{~g}$ of calcium with milk, the I experimental group - 39.41 $\mathrm{g}$ and the II experimental group - $40.28 \mathrm{~g}$, which is $5.3 \%(\mathrm{P} \leq 0,05)$ significantly more than the animals of the control group and $2.21 \%$ in comparison with the I experimental group. It was found that the animals had a positive balance of calcium in the control group of 16.43 $\mathrm{g}$, in the I experimental group - $16.97 \mathrm{~g}$ and in the II experimental group - $17.69 \mathrm{~g}$, which indicates a sufficient intake of this element with feed.

In the body of cows of the control group, $96.7 \mathrm{~g}$ of phosphorus was received with feed, in the I experimental group - by $1.55 \%$ and in the II experimental group - by $3.72 \%$ more than in the control group (Table 4).

Table 4. Phosphorus balance and use, $g /$ day, $(n=3)$.

\begin{tabular}{|c|c|c|c|}
\hline \multirow{2}{*}{ Indicator } & \multicolumn{3}{|c|}{ Group } \\
\cline { 2 - 4 } & control & I experimental & II experimental \\
\hline Taken with feed & 96.7 & 98.2 & 100.3 \\
\hline Excreted in feces & $52.28 \pm 0.14$ & $52.54 \pm 0.21$ & $52.11 \pm 0.15$ \\
\hline Excreted in urine & $13.31 \pm 0.06$ & $13.23 \pm 0.08$ & $12.92 \pm 0.31$ \\
\hline Excreted in milk & $24.10 \pm 0.17$ & $24.19 \pm 0.09$ & $25.38 \pm 0.28^{*}$ \\
\hline Held in body & $7.01 \pm 0.64$ & $8.24 \pm 0.96$ & $9.89 \pm 0.73^{*}$ \\
\hline Total use from intake, \% & $32.17 \pm 0.82$ & $33.02 \pm 0.78$ & $35.16 \pm 2.64$ \\
\hline incl. for milk, \% & $24.92 \pm 0.29$ & $24.63 \pm 0.25$ & $25.30 \pm 0.37$ \\
\hline
\end{tabular}

Cows of the II experimental group isolated phosphorus from milk significantly more by $5.31 \%(\mathrm{P} \leq 0,05)$ than the animals of the control group. The retention of phosphorus in the body of control cows was $7.01 \mathrm{~g}$, of experimental animals $-8.24-9.89 \mathrm{~g}$.

The blood biochemical parameters of experimental animals reflect the functional state of the cow's body (Table 5).

Table 5. Biochemical parameters of animal blood in the period of physiological experiment, $(n=3)$.

\begin{tabular}{|c|c|c|c|c|}
\hline \multirow{2}{*}{ Indicator } & \multirow{2}{*}{ Norm } & \multicolumn{3}{|c|}{ Group } \\
\cline { 3 - 5 } & & control & I experimental & II experimental \\
\hline Total protein, g/l & $70-92$ & $72.58 \pm 1.17$ & $71.36 \pm 0.84$ & $73.74 \pm 1.03$ \\
\hline Urea, mmol/1 & $2.35-7.06$ & $4.22 \pm 0.43$ & $4.85 \pm 0.57$ & $5.07 \pm 0.74$ \\
\hline Alkaline phosphatase, $\mathrm{u} / 1$ & $18.0-153.0$ & $97.16 \pm 1.02$ & $96.14 \pm 0.96$ & $99.29 \pm 1.96$ \\
\hline Glucose, $\mathrm{mmol} / 1$ & $1.65-4.19$ & $1.78 \pm 0.03$ & $1.82 \pm 0.04$ & $1.94 \pm 0.15$ \\
\hline Calcium, mmol/1 & $2.03-3.14$ & $2.44 \pm 0.03$ & $2.47 \pm 0.02$ & $2.51 \pm 0.05$ \\
\hline Phosphorus, mmol/1 & $1.13-2.90$ & $1.59 \pm 0.02$ & $1.62 \pm 0.03$ & $1.67 \pm 0.07$ \\
\hline AST, u/l & $46-108$ & $73.41 \pm 2.37$ & $78.23 \pm 3.84$ & $76.03 \pm 2.61$ \\
\hline ALT, u/l & $12-40$ & $29.35 \pm 1.29$ & $27.28 \pm 1.93$ & $31.12 \pm 1.54$ \\
\hline Carotene, $\mathrm{mg} \%$ & $0.4-1.0$ & $0.46 \pm 0.02$ & $0.48 \pm 0.02$ & $0.50 \pm 0.04$ \\
\hline
\end{tabular}

The biochemical analysis of the blood of the experimental cows showed that during the physiological experiment, there were no significant differences in the metabolic processes in the animals. The blood biochemical parameters corresponded to the reference values.

It was found that the blood of the control group animals contained $2.44 \mathrm{mmol} / \mathrm{l}$ of calcium, $2.47 \mathrm{mmol} / 1$ in the I experimental group and $2.51 \mathrm{mmol} / 1$ in the II experimental group. According to the phosphorus content in the blood, there is a slight increase in the I experimental group by $1.89 \%$ and $5.03 \%$ in the II experimental group compared to the control. In general, there were no significant differences in the content of calcium and phosphorus in the blood serum between the groups.

Thus, the studied energy supplements "Cow Energy" and "Ketostop El" did not have a negative effect on the hematological status of the experimental cows. 
During the physiological experiment, there was an increase in daily milk yield in cows of the II experimental group, who consumed the Ketostop El energy supplement as part of the diet, by $1.98 \mathrm{~kg}$ more than in the control group and by $6.80 \%$ more than in the I experimental group, who received the Cow Energy supplement (Table 6).

Table 6. Indicators of milk productivity of lactating cows during physiological experiment period

\begin{tabular}{|c|c|c|c|}
\hline \multirow{2}{*}{ Indicator } & \multicolumn{3}{|c|}{ Group } \\
\cline { 2 - 4 } & control & I experimental & II experimental \\
\hline Milk yield per day, kg & $24.87 \pm 0.21$ & $25.14 \pm 0.26$ & $26.85 \pm 1.81$ \\
\hline Mass content of protein in milk, \% & $3.11 \pm 0.02$ & $3.13 \pm 0.02$ & $3.17 \pm 0.05$ \\
\hline Milk protein yield, kg & $3.88 \pm 0.03$ & $3.93 \pm 0.04$ & $4.26 \pm 0.09^{*}$ \\
\hline Mass content of fat in milk, \% & $3.69 \pm 0.02$ & $3.75 \pm 0.03$ & $3.78 \pm 0.04$ \\
\hline Milk fat yield, kg & $4.59 \pm 0.06$ & $4.71 \pm 0.08$ & $5.07 \pm 0.10^{*}$ \\
\hline
\end{tabular}

In the milk of cows of the II experimental group, the protein and fat content was $3.17 \%$ and $3.78 \%$, which is $0.06 \%$ and $0.09 \%$ more than the control. In the milk of cows of the I experimental group, the protein and fat content was $3.13 \%$ and $3.75 \%$, which is $0.02 \%$ and $0.06 \%$ more than the control. The amount of milk protein and milk fat in the control group was $3.88 \mathrm{~kg}$ and $4.59 \mathrm{~kg}$, which is $1.28 \%$ and $2.55 \%, 8.92 \%$ and $9.47 \%$ less than in the I experimental and II experimental groups, respectively.

Thus, the feeding of energy supplements "Cow Energy" and "Ketostop El" in the diets of lactating cows had a positive effect on milk synthesis.

\section{Conclusions}

The conducted studies on the effect of feeding the energy feed supplements "Cow Energy" and "Ketostop El" in the diet of lactating cows in the first phase of lactation on the digestibility and absorption of macronutrients allow to conclude that the calcium and phosphorus of the experimental groups cow feed were better used. The inclusion of the supplement "Ketostop El" in the diet of lactating cows in the amount of $200 \mathrm{~g}$ per head per day increases the level of daily milk yield - by $7.96 \%$, the amount of fat in milk - by $0.09 \%$, protein - by $0.06 \%$.

\section{References}

1. A.I. Ovsyannikov, Fundamentals of experimental business in animal husbandry, Moscow, 303 (1976)

2. N.A. Plokhinsky, Guide to biometrics for animal technicians, Moscow, 256 (1969)

3. A.P. Kalashnikov, V.I. Fisinin, V.V. Shcheglov, Norms and diets of farm animals: reference manual, Moscow, 456 (2003)

4. T. Krober, Anim, Res. 50 (1), 5-20 (2001)

5. S.F. Ledgard, Proceedings of the New Zealand Grassland Association, 66, 69-74 (2004)

6. N. Martinez, L.D. Sinedino, R.D. Bisinotto, Journal of Dairy Science. 97, 874-887 (2014)

7. M. Stevenson, New Zealand Veterinary Journal, 47 (2), 53-60 (1999) 
8. N.B. Nikulina, L.V. Sycheva, V.M. Aksenova. Assessment of the factors influencing the fertility of dairy cows IOP Conf. Ser. Earth and Environmental Sci, 341, 012040 (2019)

9. O.I. Iunusova, L.V. Sycheva, V.A. Sitnikov, A.N. Popov, A.I. Panyshev, Res. J. of Pharmac., Biol. and Chem. Sci. 7(1) 2169-74 (2016) 